https://jurnal.univpgri-

palembang.ac.id/index.php/luminous

\title{
PENGARUH MODEL PEMBELAJARAN CONTEXTUAL TEACHING AND LEARNING (CTL) BERBANTUAN ALAT PERAGA TERHADAP PEMAHAMAN KONSEP FISIKA SISWA SMA
} Dea Tirsa Yolanda ${ }^{1}$, Patricia Lubis ${ }^{2}$, Sugiarti ${ }^{3}$

1,2,3 Program Studi Pendidikan Fisika, FKIP, Universitas PGRI Palembang 1'deatirsay@gmail.com, ${ }^{2}$ patricialubis@gmail.com, ${ }^{3}$ sugiartialatiq@gmail.com

\begin{abstract}
Abstrak
Masalah dalam penelitian adalah rendahnya pemahaman konsep Fisika siswa. Penelitian ini bertujuan untuk mengetahui pengaruh penggunaan model pembelajaran contextual teaching and learning berbantuan alat peraga terhadap pemahaman konsep Fisika siswa SMA Negeri 11 Palembang. Metode penelitian yang digunakan adalah quasi experimental design dengan menggunakan desain nonrandomized control group pretest-postest design. Pengambilan sampel menggunakan teknik sampling purposive sehingga diperoleh kelas XI.IPA 2 sebagai kelas eksperimen dan XI.IPA 1 sebagai kelas kontrol. Teknik pengumpulan data menggunakan tes dan dokumentasi. Teknik analisis data tes menggunakan uji-t. Berdasarkan hasil analisis data tes diperoleh nilai rata-rata pos-test kelas eksperimen sebesar 86,24 sedangkan kelas kontrol 70,48. Hasil uji hipotesis menggunakan uji-t pada taraf signifikan 5\% diperoleh $t_{\text {hitung }}>t_{\text {tabel }}$ yakni 12,21 $>1,67$ maka diartikan bahwa Ha diterima dan Ho ditolak. Sehingga dapat disimpulkan bahwa ada pengaruh yang signifikan penggunaan model pembelajaran contextual teaching and learning berbantuan alat peraga terhadap pemahaman konsep Fisika siswa.
\end{abstract}

Kata kunci : Contextual Teaching And Learning, Alat Peraga, Pemahaman Konsep Fisika.

(C) 2020 Pendidikan Fisika FKIP UPGRI Palembang

\section{PENDAHULUAN}

Pelajaran fisika merupakan salah satu materi yang diajarkan di sekolah. Fisika dalam bahasa Yunani adalah fysikos yang bearti alamiah dan fysis yang bearti alam. Jadi fisika adalah ilmu yang mempelajari gejala alam secara keseluruhan. Fisika mempelajari materi, energi, dan fenomena atau kejadian alam, baik yang bersifat makropis (berukuran besar, seperti gerak bumi mengelilingi matahari) maupun yang bersifat mikropis (berukuran kecil, seperti gerak elektron mengelilingi bumi) yang berkaitan dengan perubahan zat atau energi (Lefudin, 2016, hal. 1). Salah satu materi fisika yang dipelajari disekolah adalah materi getaran sub pokok elastisitas dan hukum hooke. Elastisitas adalah kemampuan suatu benda untuk kembali ke keadaan semula setelah gaya yang dikenakan padanya dilepaskan. Sedangkan hukum hooke adalah pertambahan panjang pada pegas sebanding dengan besar gaya yang bekerja (Siswanto \& Sukaryadi, 2009, hal. 60-71).

Pelajaran fisika memiliki banyak manfaat tidak hanya pada fenomena alam tetapi juga 
dalam perkembangan teknologi saat ini. Misalnya ketika kita mengendarai motor atau mobil, laju motor pasti selalu berubah-ubah penerapan ini terdapat pada materi gerak lurus beraturan yang ada di pelajaran fisika. Hal ini berguna agar tidak tabrakan dengan pengendara lain apalagi saat kondisi jalan ramai. Pada materi elastisitas dan hukum hooke terdapat salah satu penerapanya yaitu pada shock motor yang berguna untuk meredam kejutan saat sepeda motor diperlambat atau saat mengalami benturan keras karena disebabkan jalanan yang tidak rata. Sedangkan dibidang teknologi, manfaat pelajaran fisika banyak kita temui di bidang kedokteran salah satunya terapi three dimensional conformal radiotherapy (3D-CRT), yang dapat mengembangkan metode pembedahan dengan menggunakan radiasi pengion sebagai pisau bedahnya. Sedangkan di dalam kehidupan sehari-hari bisa kita temui pada buah jatuh dari pohon, saat kita bercermin dan masi banyak lagi. Melihat dari beberapa penjelasan tersebut oleh sebab itu kenapa pelajaran fisika dianggap penting.

Materi pada pelajaran fisika terdiri dari fisika klasik (mekanika, termodinamika, gelombang) dan fisika modern (fisika kuantum, fisika zat padat, fisika inti) yang menuntut agar siswa mampu memahami konsep. Sedangkan pemahaman konsep menurut Bloom (Anderson \& Krathwohl, 2017, hal. 106-114) terdapat tujuh indikator ranah kognitif memahami yaitu kemampuan siswa dalam penerjemahan atau interprestasi (interpreting), memberikan contoh (exemplifying) yaitu menemukan contoh-contoh yang spesifik, mengklasifikasikan (classifying) yaitu membedakan sesuatu berdasarkan kategorinya, menggeneralisasikan atau meringkas (summarizing) yaitu membuat ringkasan secara umum, inferensi atau berpendapat (inferring) yaitu memberikan gambaran tentang kesimpulan yang logis, membandingkan (comparing) yaitu mendeteksi hubungan antara dua ide atau obyek, menjelaskan (explaining) yaitu mengkonstruksi model sebab-akibat. Dari ketujuh indikator ini sehingga tidak banyak siswa beranggapan bahwa pelajaran fisika itu sulit.

Menurut Purwanto (2012, dikutip Sastriani \& Halim, Jurnal Pendidikan Sains Indonesia, Vol. 4, No. 2, 2016, hal. 89) kemampuan memahami konsep adalah kemampuan yang mengharapkan siswa mampu memahami arti, situasi serta fakta yang diketahuinya. Selain itu, berawal dari pemahaman konsep siswa mampu menghadapi variasi bentuk soal fisika. Oleh karena itu pemahaman konsep dianggap penting karena pemahaman konsep fisika merupakan modal dasar atas perolehan hasil belajar yang memuaskan dievaluasi akhir nanti. Sesuai dengan pernyataan Mauke, et al. (eJurnal Program Pascasarjana Universitas Pendidikan Ganesha, Vol. 3, 2013) bahwa dalam proses pembelajaran siswa harus memiliki pemahaman tentang konsep, karena konsep-konsep merupakan dasar bagi prosesproses mental yang lebih tinggi untuk merumuskan prinsip-prinsip dan generalisasigeneralisasi.

Pada saat melaksanakan kuliah praktik pengalaman lapangan (PPL), observasi dan wawancara terhadap guru mata pelajaran fisika kelas XI di SMA Negeri 11 Palembang. Hasil 
dari observasi dan wawancara tersebut bahwa keadaan sekolah ini cukup baik, karena semua fasilitas yang diperlukan dalam pembelajaran hampir semuanya ada. Misalnya setiap kelas memiliki proyektor, speaker, mempunyai laboratorium, ruang esktra kulikuler, masjid dan lain-lain. Serta sekolah ini terakreditasi "A" (amat baik) dan disekolah ini suda menerapkan kurikulum 2013. Tetapi dari semua fasilitas yang baik ini ditemukan adanya kendala dalam pemahaman konsep. Kendala tersebut dapat dilihat dari persentase hasil ulangan siswa kelas XI tahun 2017/2018 hanya 30\%-70\% saja, sedangkan keberhasilan belajar yang diharapkan adalah $85 \%$ dari seluruh siswa yang mencapai kriteria ketuntasan minimal (KKM). Dimana nilai dari kriteria ketuntasan minimal (KKM) yakni 67. Adapun faktor penyebab dari hal tersebut adalah proses pembelajaran yang kurang optimal. Dalam hal ini diantaranya model pembelajaran belum bervariasi sesuai dengan kebuthan materi yang akan disampaikan, model pembelajaran yang menggunakan alat peraga pada materi elastisitas dan hukum hooke belum pernah digunakan oleh guru mata pelajaran, kurangnya alat peraga sebagai media penunjang pembelajaran fisika untuk materi elastisitas dan hukum hooke, dan guru masih menjadi pusat pembelajaran dikelas. Hal ini mengakibatkan minimnya pemahaman konsep fisika siswa pada materi elastisitas dan hukum hooke.

Berdasarkan permasalahan tersebut maka perlu dilakukan perubahan dalam model dan strategi mengajar. Salah satu model pembelajaran yang sesuai dengan hal tersebut adalah model pembelajaran contextual teaching and learning (CTL).

Menurut Hosnan (2016, hal. 267) model contextual teaching and learning adalah konsep belajar dimana guru menghadirkan dunia nyata kedalam kelas serta mendorong siswa membuat hubungan antara pengetahuan yang dimilikinya dengan penerapannya dalam kehidupan mereka sehari-hari. Berdasarkan hal tersebut maka pembelajaran kontekstual adalah konsep yang mengaitkan materi pelajaran yang dipelajari siswa dengan konteks kegunaan serta hubungan materi tersebut dengan kehidupan dan cara belajar siswa itu sendiri.

Hal itu juga serupa dengan pemikiran Trianto (2013, hal. 104-105) yang menyatakan bahwa model pembelajaran contextual teaching and learning merupakan suatu konsepsi yang membantu guru mengaitkan konten mata pelajaran dengan situasi dunia nyata dan memotivasi siswa membuat hubungan antara pengetahuan dan penerapannya dalam kehidupan mereka. Serta dipertegas lagi oleh Sumiati \& Asra (2012, hal. 14) mengatakan bahwa pembelajaran kontekstual terfokus pada perkembangan ilmu, pemahaman, keterampilan siswa dan juga pemahaman kontekstual siswa tentang hubungan mata pelajaran yang dipelajarinya dengan dunia nyata. Melihat hakikat dari beberapa ahli tersebut, maka model pembelajaran ini sangat cocok dengan permasalahan yang ditemui peneliti dan tujuh indikator menurut Bloom yang dapat dikatakan siswa telah memahami konsep.

Penjelasan tersebut dapat dibuktikan dengan penelitian sebelumnya tentang hubungan model pembelajaran CTL dengan 
pemahaman konsep. Seperti yang dibuktikan oleh Mauke, et al. (e-Journal Program Pascasarjana Universitas Pendidikan Ganesha, Vol. 3, 2013) yang menyatakan bahwa terdapat perbedaan pemahaman konsep yang signifikan antara kelompok belajar yang menggunakan model CTL dan model pembelajaran konvensional dalam pembelajaran IPA-Fisika di MTS Negeri Negara. Hal ini juga dibuktikan oleh Cokera, et al. (Procedia Social and Behavioral Sciences, Vol. 2, No. 1488-1492, 2010) dalam penelitian "conceptions of students about renewable energy sources: a need to teach based on contextual approaches" yang menyatakan bahwa siswa yang belajar secara kontekstual akan lebih baik dalam memahami konsep-konsep, isu-isu lingkungan dan sosial terkait.

Sehingga hal ini dapat kita tarik kesimpulan bahwa model pembelajaran kontekstual dapat mempengaruhi pemahaman konsep siswa menjadi lebih baik lagi. Serta model pembelajaran kontekstual adalah model pembelajaran yang mengharuskan siswa untuk mandiri dan lebih banyak dalam belajar yang mengharuskan guru harus lebih kreatif dalam menyampaikan materi agar dapat disampaikan kepada siswa kegunaan materi yang dipelajari dalam konteks kehidupan sehari-hari. Salah satunya yaitu dalam proses pembelajaran, guru harus menggunakan media pembelajaran.

Media pembelajaran memegang perananan yang penting dalam proses pembelajaran. Penggunaan media pembelajaran dapat membantu dalam menyampaikan materi pembelajaran apalagi dengan keterbatasan waktu guru mengajar, dengan media pembelajaran bab pelajaran yang tergolong banyak dapat dijelaskan dalam satu kemasan seperti alat peraga. Menurut Ali (dikutip dari Nur \& Sumarni, Jurnal Inovasi Pendidikan Kima, Vol. 11, No. 1, 2017) fungsi media pembelajaran dalam proses belajar mengajar yaitu untuk meningkatkan rangsangan peserta didik dalam kegiatan belajar. Sehingga peneliti merasa perlu adanya bantuan media pembelajaran dalam hal ini yaitu alat peraga sederhana untuk mendukung model pembelajaran contextual teaching and learning.

Menurut Sudjana (2014, hal. 110), alat peraga adalah alat bantu dalam proses pengajaran yang berfungsi untuk memperjelas guru saat mengajar dan siswa saat belajar. Jadi alat peraga dalam mengajar memegang peranan penting sebagai alat bantu untuk menciptakan proses belajar-mengajar yang efektif. Alat peraga juga dapat mengoptimalkan waktu yang cenderung sedikit, sedangkan materi yang harus disampaikan lumayan banyak, karena didalam alat peraga bisa menyampaikan beberapa konsep yang dikemas menjadi satu. Alat peraga yang digunakan ini yaitu alat peraga pada mata pelajaran fisika materi elastisitas dan hukum hooke.

Berdasarkan dari penjelasan diatas pengunaan model pembelajaran contextual teaching and learning berbantuan alat peraga pada mata pelajaran fisika, dapat dijadikan model pembelajaran dan media yang sangat inovatif, efektif dan efisien dalam pembelajaran. Tujuan dari penelitian ini adalah untuk mengetahui pengaruh penggunaan model pembelajaran contextual teaching and learning (CTL) berbantuan alat peraga terhadap 
pemahaman konsep fisika siswa SMA Negeri 11 Palembang.

\section{METODE}

Penelitian ini dilaksanakan selama dua minggu yaitu mulai tanggal 6 Agustus sampai 20 Agustus 2018 semester genap tahun ajaran 2018/2019. Metode yang digunakan pada penelitian ini adalah metode quasi experimental design, dengan menggunakan desain nonrandomized control group pretest-postest design (Sukardi, 2016, hal. 186). Bagan desain penelitian nonrandomized control group pretestpostest design yaitu:

\begin{tabular}{lccc}
\hline Grup & Pretes & Variabel Terikat & $\begin{array}{c}\text { Postt } \\
\text { es }\end{array}$ \\
\hline $\begin{array}{l}\text { Eksperime } \\
\mathrm{n}\end{array}$ & $\mathrm{Y}_{1}$ & $\mathrm{X}$ & $\mathrm{Y}_{2}$ \\
\hline Kontrol & $\mathrm{Y}_{3}$ & $\mathrm{Z}$ & $\mathrm{Y}_{4}$
\end{tabular}

Gambar 1. Nonrandomized Control Group PretestPostest Design (Sukardi, 2016, Hal. 186)

Keterangan :

$\mathrm{Y}_{1}$ : Soal pretes pada kelas eksperimen (menggunakan model pembelajaran CTL berbantuan alat peraga)

$\mathrm{Y}_{2}$ : Soal postes pada kelas eksperimen (menggunakan model pembelajaran CTL berbantuan alat peraga)

$\mathrm{Y}_{3}$ : Soal pretes pada kelas kontrol (menggunakan model pembelajaran DI)

$\mathrm{Y}_{4}$ : Soal postest pada kelas kontrol (menggunakan model pembelajaran DI)

X : Perlakuan pada kelas eksperimen (menggunakan model pembelajaran CTL berbantuan alat peraga)

Z : Tidak ada perlakuan pada kelas kontrol (menggunakan model pembelajaran DI)
Populasi dalam penelitian ini adalah seluruh peserta didik kelas XI IPA yang terbagi dalam enam kelas, sampel ditentukan dengan teknik sampling purposive dan diperoleh kelas XI IPA 1 sebagai kelas kontrol dan kelas XI IPA 2 sebagai kelas eksperimen. Kelas eksperimen dengan menggunakan model pembelajaran CTL berbantuan alat peraga dan kelas kontrol yang menggunakan model pembelajaran direct instruction, setelah itu kedua kelas diberikan tes awal yang disebut pre-test dan tes akhir yang disebut post-test. Diberikannya tes awal dan tes akhir ini guna melihat pengaruh dari pembelajaran CTL berbantuan alat peraga. Soal tes yag diberikan berbentuk essay sebanyak 7 soal dengan rincian untuk soal pada ranah kognitif memahami. Materi yang diajarkan dalam penelitian ini adalah elastisitas dan hukum hooke.

Variabel bebas dalam penelitian ini adalah model pembelajaran contextual teaching and learning (CTL) berbantuan alat peraga dan variabel terikatnya adalah pemahaman konsep fisika. Instrumen yang digunakan berupa tes uraian yang telah valid, reliable, uji daya pembeda dan memiliki tingkat kesukaran serta dokumentasi. Analisis uji hipotesis menggunakan uji-t yang datanya telah terdistribusi normal dan homogen.

Pemahaman konsep yang diteliti pada penelitian ini terdiri dari tujuh indikator menurut Bloom (Anderson \& Krathwohl, 2017, hal. 106114) yaitu interprestasi (penerjemahan), mencontohkan, mengklasifikasikan, menggenaralisasikan (meringkas), inferensi (berpendapat), membandingkan, dan menjelaskan (explaining). 


\section{HASIL DAN PEMBAHASAN}

Hasil penelitian yang dilaksanakan di SMA Negeri 11 Palembang pada tahun 2018/2019 yaitu untuk mengetahui pengaruh model pembelajaran contextual teaching and learning (CTL) berbantuan alat peraga terhadap pemahaman konsep fisika siswa SMA Negeri 11 Palembang. Proses penelitian ini menggunakan dua kelas yang terdiri dari kelas XI IPA 2 sebagai kelas eksperimen dengan jumlah siswa sebanyak 37 orang dan kelas XI IPA 1 sebagai kelas kontrol dengan jumlah siswa sebanyak 37 orang. Penelitian ini menggunakan teknik pengumpulan data berupa tes yang dilaksanakan pada awal pembelajaran (tes awal atau Pre-test) dan akhir pembelajaran (tes akhir atau pos-test) serta pengumpulan data dokumentasi. Berdasarkan hasil pre-test dan pos-test pemahaman konsep siswa pada kelas eksperimen dan kontrol diperoleh data hasil tes yang dapat dilihat pada tabel berikut:

Tabel 1. Data Hasil Pre-test dan Pos-test Kedua Kelas

\begin{tabular}{lccc}
\hline Data & Skor & Kelas Kontrol & Kelas Eksperimen \\
\hline \multirow{3}{*}{ Pre Test } & Banyak Data & 37 & 37 \\
& Skor Terendah & 33 & 38 \\
& Skor Tertinggi & 62 & 67 \\
& Rata-rata & 49,05 & 52,83 \\
\hline \multirow{4}{*}{ Post Test } & Banyak Data & 37 & 37 \\
& Skor Terendah & 57 & 71 \\
& Skor Tertinggi & 86 & 100 \\
\hline
\end{tabular}

Tabel 1 menunjukkan hasil tes awal dan tes akhir siwa kelas eksperimen dan kelas kontrol. Berdasarkan tabel 1 rata-rata nilai siswa saat tes awal (pre-teest) untuk kelas eksperimen dan kontrol tidak terlalu jauh perbedaanya, yaitu 49,05 untuk kelas kontrol dan 52,83 untuk kelas eksperimen. Sedangkan saat tes akhir (postest) rata-rata nilai siswa yang diperoleh cukup terlampau jauh perbedaanya, yaitu 70,48 untuk kelas kontrol dan 86,24 untuk kelas eksperimen. Hal ini terjadi karenaa saat tes akhir kelas eksperimen telah diberi perlakuan dalam proses pembelajaran yaitu dengan menggunakan model pembelajaran contextual teaching and learning berbantuan alat peraga, sedangkan untuk kelas kontrol diberi perlakuan dengan model pembelajaran konvensional yaitu model pembelajaran direct intruction.

Berdasarkan hasil dari tes akhir pada kedua kelas maka didapat perolehan hasil mengenai 7 indikator pemahaman konsep siswa yang menunjukka bahwa persentase pemahaman konsep kelas eksperimenn lebih tinggi dibandingkan kelas kontrol. Hal ini dapat kita liha pada uraian berikut:

1. Pada indikator menjelaskan, di kelas eksperimen menunjukkan bahwa persentase peserta didik dalam menjelaskan sebesar 82,9\% sedangkan kelas kontrol 66,67\%. Hal ini menunjukkan adanya perbedaan yang signifikan pada pemahaman konsep peserta didik dalam indikator menjelaskan. Perbedaan ini dikarenakan pada kelas eksperimen peserta didik langsung ikut serta dalam proses pembelajaran dan peserta didik dapat secara langsung membuktikan 
penjelasan peneliti mengenai elastisitas dan hukum hooke dengan alat peraga yang disediakan. Hal ini sejalan dengan pemikiran Shoimin (2014, hal. 44) bahwa pembelajaran kontekstual dapat menjadikan siswa belajar bukan dengan menghafal, melainkan proses berpengalaman dalam kehidupan nyata dan bukan sebagai tempat untuk memperoleh informasi, melainkan tempat untuk menguji data hasil temuan mereka dilapangan. Sedangkan pada kelas kontrol siswa hanya mendengarkan dan menyimak yang dijelaskan peneliti.

2. Pada indikator memberikan contoh, untuk kelas eksperimen persentase pemahaman konsep pada indikator memberikan contoh sebesar $88 \%$ sedangkan pada kelas kontrol sebesar $81,08 \%$. Dari hasil menunnjukkan adanya perbedaan pemahaman konsep siswa pada indikator memberikan contoh tetapi tidak terlalu signifikan perbedaanya. Dalam memberikan contoh kedua kelas dapat memahaminya walaupun terdapat perbedaan. Hal ini dikarenakan pada kelas eksperimen peserta didik langsung dapat melihat contoh benda-benda elastis atau non elastis dan membuktikannya melalui praktikum, sedangkan pada kelas kontrol peserta didik hanya dapat membayangkanya.

3. Pada indikator berpendapat, kelas eksperimen memiliki persentase sebesar $84,68 \%$ yang berbanding jauh dengan kelas kontrol yaitu sebesar 66,67\%. Hal ini dikarenakan kelas eksperimen pada indikator berpendapat peserta didik dalam proses pembelajaran selain melakukan praktikum juga melakukan diskusi yang lansung dibimbing oleh peneliti mengenai elastisitas dan hukum hooke. Sedangkan dikelas kontrol peserta didik melakukan diskusi tetapi tidak dibimbing oleh peneliti dan diskusi yang dilakukan tidak efektif karena tidak ada contoh secara langsung yang dapat mereka lihat.

4. Pada indikator mengkalsifikasikan, untuk kelas eksperime persentase pada indikator ini yang diperoleh sebesar $85,6 \%$ sedangkan kelas kontrol persentase yang diperoleh sebesar 70,17\%. Hal ini menunjukkan adanya perbedaan pada pemahaman konsep indikator mengklasifikasikan, dikarenakan pada saat proses pembelajaran kelas eksperimen diberikan demonstarsi secara langsung mengenai elastisitas dan hukum hooke dengan menggunakan alat peraga yang bisa mereka temui dalam kehidupan seharihari serta siswa diajak untuk melakukan praktikum. Sedangkan dikelas kontrol peneliti hanya menjelaskan dan tidak melakukan demonstrasi. Sehingga saat mejawab peserta didik dikelas kontrol kebanyakan tidak bisa mengklasifikasikan soal tersebut.

5. Pada indikator menggeneralisasikan, dikelas eksperimen menunjukkan bahwa persentase yang didapat sebesar $80,18 \%$ sedangkan dikelas kontrol 63,96\%. Hal tersebut menunjukkan bahwa adanya perbedaan dan pada indikator menggeneralisasikan merupakan persentase terendah untuk kedua kelas. 
Hal ini terjadi dikarenakan peserta didik baik dikelas eksperimen dan kelas kontrol belum menguasai indikator menggenealisasikan, sehingga ada kesalahan saat menjawab.

6. Pada indikator penerjemahan, dikelas eksperimen menunjukkan persentase pemahaman konsep indikator penerjemahan sebesar $90,99 \%$ yang merupakan persentase tertinggi pada kelas ini, sedangkan dikelas kontrol sebesar $68,47 \%$. Melihat persentase ini terdapat perbedaan yang signifikan antara kelas ekspeerimen dan kelas kontrol. Perbedaan terjadi dikarenakan ada sebagian peserta didik kelas eksperimen ataupun kelas kotrol hanya menjawab tetapi tidak menguraikan definisinya.

7. Pada indikator membandingkan, pada kelas eksperimen menunjukkan bahwa persentase peserta didik dalam membandingkan lebih tinggi dibandingkan kelas kontrol, dimana kelas eksperimen sebesar $90 \%$ sedangkan kelas kontrol $81,08 \%$. Hal ini menunjukkan bahwa ada perbedaan persentase pada kelas eksperimen dan kelas kontrol. Hal ini terjadi dikarenakan peserta didik mengatakan kurangnya waktu dan yang dikerjakan merupakan soal hitungan.

Berdasarkan hasil tes mengenai pemahaman konsep tiap indkator menunjukkan bahwa adanya perbedaan pada kelas eksperimen dan kelas kontrol. Berdasarkan data tersebut kelas eksperimen memiliki persentase yang lebih tinggi setelah menggunakan model pembelajaran CTL berbantuan alat peraga.
Besarnya persentase pemahaman konsep siswa dikarenakan saat proses pembelajaran peserta didik dikelas eksperimen pada kegiatan awal diberikan demonstrasi dengan alat peraga yang dapat dilihat dan digunakan dalam kehidupan sehari-hari, kemudia peserta didik melakukan kegiatan langsung dengan dibimbing oleh peneliti mealalui praktikum setelah itu pada kegiatan akhir peserta didik menjelaskan hasil praktikum serta dapat berdiskusi langsung mengenai hal yang dijelaskannya dan mengetahui penerapnnya dalam kehidupan sehari-hari peserta didik. Dengan pembelajaran CTL peserta didik dapat mengetahui dan menerapkanya dalam kehidupan sehar-hari. Hal ini sejalan dengan pendapat Trianto (2013, hal. 104-105) menyatakan bahwa model pembelajaran contextual teaching and learning merupakan suatu konsepsi yang membantu guru mengaitkan konten mata pelajaran dengan situasi dunia nyata dan memotivasi siswa membuat hubungan antara pengetahuan dan penerapannya dalam kehidupan mereka.

Sedangkan proses pembelajaran kelas kontrol lebih banyak berpusat pada peneliti dan peserta didik hanya menerima. Peserta didik hanya memperhatikan penjelasan materi yang diberikan peneliti. Hal ini sejalan dengan pernyataan Ibrahim (2017) bahwa model pembelajaran konvensional merupakan pelajaran yang beerpusat pada guru, mengutamakan hasil bukan proses, siswa ditempatkan sebagi objek dan bukan subjek pembelajaran sehingga siswa sulit mengemukakan pendapatnya. Sehingga hal inila yang menyebabkan terjadinya perbedaan 
yang signifikan persentase antara kelas eksperimen dan kelas kontrol.

Pada uji hipotesis peneliti hanya menghitung untuk tes akhir (pos-test). Hipotesis yang diuji dalam perhitungan uji-t untuk pos-test adalah:

a. $H 0: \mu_{1} \leq \mu_{2}$ : Tidak ada pengaruh yang signifikan pada model pembelajaran contextual teaching and learning berbantuan alat peraga terhadap pemahaman konsep fisika di SMA Negeri 11 Palembang.

b. $H a: \mu_{1}>\mu_{2}$ : Ada pengaruh yang signifikan pada model pembelajaran contextua teaching and learning

Tabel 2. Hasil Uji Hipotesis Pos-Test

\begin{tabular}{lcccc}
\hline Tes & thitung & Dk & t tabel & Kesimpulan \\
\hline Pos-test & 11,29 & 72 & 1,67 & $t_{\text {hitung }} \geq t_{\text {tabel }}$ \\
\hline
\end{tabular}

Pada tabel 2 menunjukkan hasil analisis uji-t mengenai kemampuan akhir siswa yang didapatkan nilai $t_{\text {hitung }}=11,29$ dan $t_{\text {tabel }}=1,67$ ini menunjukkan bahwa $t_{\text {hitung }} \geq t_{\text {tabel }}$ maka $\mathrm{Ha}$ diterima dan Ho ditolak. Sehingga dapat diambil kesimpulan bahwa ada pengaruh yang signifikan penggunaan model pembelajaran contextual teaching and learning berbantuan alat peraga terhadap pemahaman konsep fisika SMA Negeri 11 Palembang.

\section{SIMPULAN}

Berdasarkan hasil penelitian dan pembahasan tentang pengaruh model pembelajaran Contextual Teaching and Learning (CTL) berbantuan alat peraga terhadap pemahaman konsep fisika siswa kelas XI IPA SMA Negeri 11 Palembang pada materi Elastisitas dan Hukum Hooke, dapat diambil kesimpulan bahwa ada pengaruh yang signifikan penggunaan model pembelajaran contextual teaching and learning berbantuan alat peraga terhadap pemahaman konsep fisika SMA Negeri 11 Palembang. Hal ini terbukti dengan hasil uji hipotesis, dimana diperoleh harga nilai $t_{\text {hitung }}=11,29$ dan $t_{\text {tabel }}=1,67$ ini menunjukkan bahwa $t_{\text {hitung }} \geq t_{\text {tabel }}$ maka Ha diterima dan Ho ditolak.

Saran yang dapat diberikan peneliti terkait dengan penggunaan model pembelajaran Contextual Teaching and Learning (CTL) berbantuan alat peraga adalah sebagai berikut :

1. Bagi siswa, siswa sebaiknya harus lebih aktif dalam proses pembelajaran sehingga materi yang disampaikan akan lebih mudah diterima.

2. Bagi guru, guru harus pandai dalam mengaitkan setiap materi yang diajarkan dengan kehidupan sehari-hari peserta didik sehingga model pembelajaran CTL yang diberikan sesuai dengan hakikatnya dan guru harus benar-benar mampu menguasai tujuh indikator pemahaman konsep sehingga dalam pembuatan soal tes awal ataupun tes akhir akan terasa lebih mudah.

3. Bagi sekolah, hendaknya dapat memperhatikan kembali alat-alat dilaboratorium fisika, sehingga alat peraga yang digunakan guru dapat bervariasi.

4. Bagi peneliti lain, untuk menyempurnakan penelitian ini mungkin peneliti lain dapat melakukan penelitian yang serupa dengan materi yang berbeda. 
5. Bagi peneliti, alat peraga yang digunakan harus sudah terakit seutuhnya, sehingga tidak memakan waktu dalam proses pembelajaran

\section{DAFTAR PUSTAKA}

Achmad Vandian Nur, W. S. (2017). Pengaruh Penggunaan Metode Pembelajaran Guided Note Taking Berbantuan Media Kimmy-Games Terhadap Pemahaman Konsep Kimia Siswa SMA. Jurnal Inovasi Pendidikan Kimia , XI, 1910-1920.

Asra, S. \&. (2012). Metode Pembelajaran . Bandung: CV Wacana Prima.

Bunyamin Cokera, H. C. (2010). Conceptions of Students about renewable energy sorces: a need to teach based on contextual approaches. Procedia Social Behavioral Sciences , 2, 1488-1492.

Halim, E. S. (2016). Pembelajaran CTL Berbasis Inkuiri untuk Meningkatkan Pemahaman Konsep dan Motivasi Belajar Siswa pada Materi Fluida Statis. Jurnal Pendidikan Sains Indonesia , IV, 89-95.

Krathwohl, L. W. (2017). Kerangka Landasan Untuk Pembelajaran, Pengajaran, dan Asesmen. Yogyakarta: Pustaka Pelajar. Lefudin. (2016). Fisika Modern. Palembang: Fakultas Keguruan dan IImu Pendidikan
Program Studi Pendidikan Fisika Universitas PGRI Palembang.

M.Hosnan. (2016). Pendekatan Saintifik dan Kontekstual dalam Pembelajaran Abad 21. Bogor: Ghalia Indonesia.

Suastra, M. M. (2013). Pengaruh Model Contextual Teaching and Learning Terhadap Pemahaman Konsep dan Kemampuan Pemecahan Masalah dalam Pembelajaran IPA-Fisika di MTS Negeri Negara. e-Journal Program Pascasarjanah Universitas Pendidikan Ganesha, III.

Shoimin, A. (2014). 68 Model Pembelajaran Inovatif dalam Kurikulum 2013. Yogyakarta: Ar-Ruzz Media.

Siswanto, S. (2009). Kompetensi Fisika Kelas XI untuk SMA/MA. Yogyakarta: PT Citra Aji Parama.

Sudjana, N. (2014). Dasar-Dasar Proses Belajar Mengajar. Bandung: Sinar Baru Algensindo.

Sukardi. (2016). Metodologi Penelitian Pendidikan. Jakarta: PT Bumi Aksara.

Trianto. (2013). Mendesain Model Pembelajaran Inovatif-Progresif. Jakarta: Kencana Prenada Media Group. 